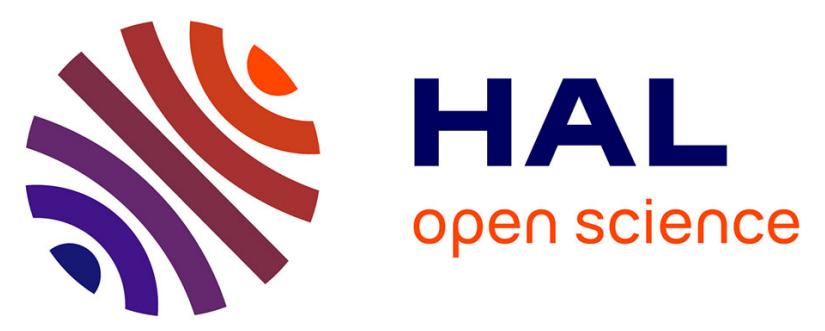

\title{
Comparison of population dynamics of atlantic salmon (Salmo salar) and brown trout (Salmo trutta) in a small tributary of the River Scorff (Brittany, France)
}

\author{
Jean-Luc J.-L. Baglinière, Etienne Prévost, Gérard Maisse
}

\section{- To cite this version:}

Jean-Luc J.-L. Baglinière, Etienne Prévost, Gérard Maisse. Comparison of population dynamics of atlantic salmon (Salmo salar) and brown trout (Salmo trutta) in a small tributary of the River Scorff (Brittany, France). Ecology of Freshwater Fish, 1994, 3, pp.25-34. 10.1111/j.16000633.1994.tb00104.x . hal-02708658

\section{HAL Id: hal-02708658 \\ https://hal.inrae.fr/hal-02708658}

Submitted on 1 Jun 2020

HAL is a multi-disciplinary open access archive for the deposit and dissemination of scientific research documents, whether they are published or not. The documents may come from teaching and research institutions in France or abroad, or from public or private research centers.
L'archive ouverte pluridisciplinaire HAL, est destinée au dépôt et à la diffusion de documents scientifiques de niveau recherche, publiés ou non, émanant des établissements d'enseignement et de recherche français ou étrangers, des laboratoires publics ou privés. 


\section{Comparison of population dynamics of Atlantic salmon (Salmo salar) and brown trout (Salmo trutta) in a small tributary of the River Scorff (Brittany, France)}

Baglinière J-L, Prévost E, Maisse G. Comparison of population dynamics of Atlantic salmon (Salmo salar) and brown trout (Salmo trutta) in a small tributary of the River Scorff (Brittany, France).

Ecology of Freshwater Fish 1994: 3: 25-34. (C) Munksgaard, 1994

Abstract - The population dynamics of Atlantic salmon (Salmo salar L.) and brown trout (Salmo trutta L.) were compared in a small tributary of the River Scorff (Brittany, France) from spawning time to the beginning of the third growing season. The spawning and fry emergence of the two species took place at approximately the same time. In the first autumn, the densityof $0+$ juveniles and settling rate from the egg stage were much higher in trout than in salmon. The emigration rate from $0+$ population was much higher in trout than in salmon. The size of resident and migrating fish was always smaller in salmon than in trout, whatever the age. The low level of salmon production in the brook, compared with trout, was the result of low survival from egg to $0+$ stage in autumn, combined with the small proportion of juveniles migrating after the first growing season. This was not compensated by a high number of migrants the next year. The role of physical habitat, inter- and intraspecific competition, predation and migration dependence on size and early sexual maturity is discussed. Indications are that small tributaries of the type studied are of great value for recruitment in trout but not very productive for juvenile salmon.

\section{J.-L. Baglinière, E. Prévost, G. Maisse}

Station d'écologie et de physiologie des poissons - INRA, Rennes, France

Key words: Atlantic salmon; brown trout; population dynamics; tributary; Brittany, France

J. L. Baglinière, Station d'écologie et de physiologie des poissons - INRA, 65 rue de St Brieuc, F-35042 Rennes cedex, France Accepted for publication March 1, 1994

Un resumen en español se incluye detrás del texto principal de este artículo.

\section{Introduction}

The River Scorff is one of the 25 salmon rivers of Armorican massif where Atlantic salmon (Salmo salar L.) cohabit with brown trout (Salmo trutta L.) (Baglinière et al. 1987a). Previous studies on salmonid biology in this system have shown that instream distribution depends on stream order and habitat requirements of each species, resulting in a relative spatial segregration: juvenile salmon were present mainly in the shallow and fast waters of the mainstem (Baglinière \& Champigneulle 1982), whereas young trout were essentially concentrated in the tributaries and in the uppermost sections of the main course (Maisse \& Baglinière 1990). Nevertheless, the two species live in sympatry in most tributaries of the R. Scorff, where salmon spawning occurred every year.

In Kernec Brook, a typical tributary of the River Scorff, analysis of population dynamics of each of the two species was carried out separately. For salmon, it was revealed that the number of migrating juveniles produced in the brook was very low (Baglinière \& Maisse 1989). This was consistent with previous observations derived from stocked fry (Baglinière 1979a). Investigations on brown trout started in 1972 (Euzenat \& Fournel 1976; Nihouarn 1983), and the most 
comprehensive study on population structure and dynamics was conducted from 1980 to $1985(\mathrm{Ba}-$ glinière et al. 1989). The importance of the brook/river system in the life history strategy of brown trout, through the relationship between resident (staying in the brook) and migratory (coming from the river to spawn in the brook) fractions of the population, was pointed out. To better understand how and why juvenile production differed between salmon and trout, this comparative study was performed.

Some other works compared these two species when coexisting in the same stream. They dealt with competitive interactions (Gibson \& Cunjak 1986; Kennedy \& Strange 1986), habitat segregation (Jones 1975; Karlström 1977; Baglinière \& Champigneulle 1982; Baglinière \& Arribe-Moutounet 1985), distribution area, population densities (Mills 1967, 1969) and production (Egglishaw 1970; Power 1973; Egglishaw \& Shackley 1977; Randall et al. 1989; Shackley \& Donaghy 1992). Data on standing populations were always derived from small sampling stations whose representativeness was not assessed. To avoid potential bias, a more rigorous approach was used on Kernec Brook. Indeed, it was based on an extensive electrofishing survey of the brook, covering the whole distribution area of salmon and almost entirely this of trout, together with the control of all the riverto-tributary exchanges, by means of a fish-counting fence located at the mouth of the brook.

In this study, the biological characteristics and the population dynamics of Atlantic salmon and brown trout during the first 3 years of life were compared in Kernec Brook for the same cohort, corresponding to a juvenile salmon density higher than usual (Baglinière unpublished data). The role of several factors, both biotic and abiotic, in accounting for the observed differences was discussed. The results obtained from Kernec Brook were also used to assess the overall value of the tributaries for recruitment of salmon and trout within the Scorff watershed.

\section{Study area}

Kernec Brook is a typical tributary of the River Scorff, flowing into the lower part of the mainstem. It is $6.7 \mathrm{~km}$ long with an average gradient of $1.3 \%$. Its mean width is $1.3 \mathrm{~m}$, varying from less than 1 $\mathrm{m}$ in the uppermost section to $2 \mathrm{~m}$ in the lower reaches. The total water surface area is $8896 \mathrm{~m}^{2}$. The habitat of the brook is characterized by a succession of pool-riffle sequences and by an abundant bank vegetation. Half of the streambed consists of coarse sand, gravel, pebbles and stones; clay, silt and fine sand together represent $34 \%$; blocks and boulders (4\%) and roots and organic debris $(12 \%)$ account for the rest of the bottom substrate. Gravel, stones and pebbles are more abundant in the lower stretch of the brook $(40 \%$ in the first $2 \mathrm{~km}$ from the mouth) than in the upper part ( $30 \%$ in the upstream last $4.7 \mathrm{~km})$. The monthly mean temperature of the water ranged from $5^{\circ} \mathrm{C}$ to $15^{\circ} \mathrm{C}$ over the study period. A more precise habitat description of the brook is provided by Haury \& Baglinière (1990).

Kernec Brook has two tributaries (Fig. 1): Kergrenn Brook and Talascorn Brook. It has been shown that the population of trout of the later was totally isolated (Baglinière et al. 1989).

Like in all the tributaries of the River Scorff, other fish species inhabit with brown trout and Atlantic salmon in Kernec Brook (Baglinière 1979b): sculpin (Cottus gobio), stone-loach (Nemacheilus barbatula), minnow (Phoxinus phoxinus), brook lamprey (Lampetra planeri) and eel (Anguilla anguilla). At the time of the study, sculpin and eel colonized the whole watercourse, whereas the other species were almost only found at the downstream end. Abundance of sculpin was very high in the lower reaches but decreased strongly when moving upstream. Such a gradient was not observed for

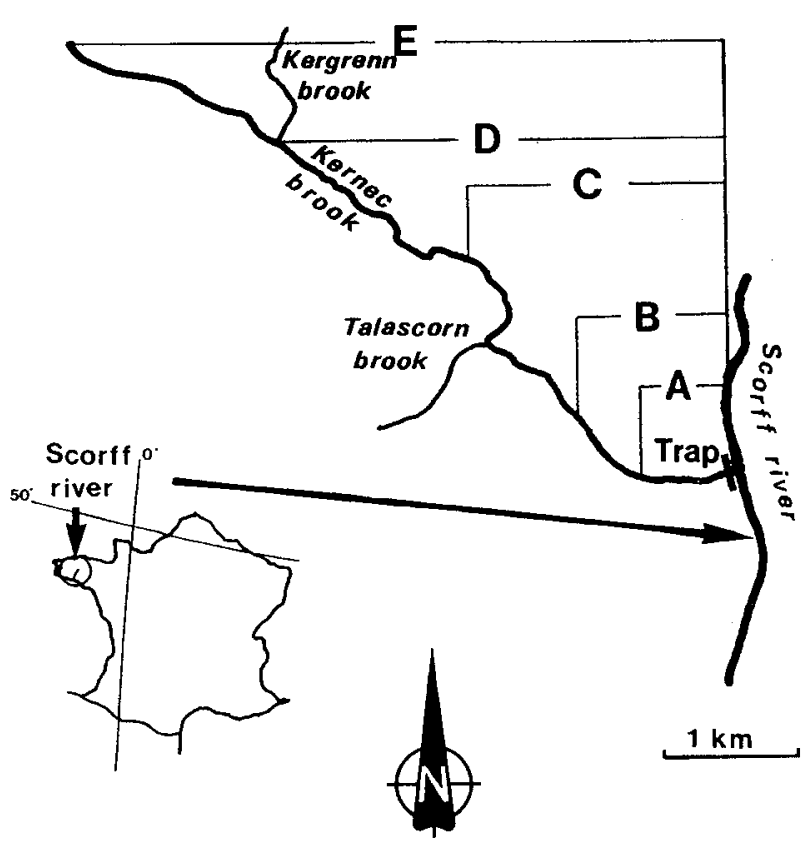

Fig. 1. Spatial distribution of brown trout and Atlantic salmon in Kernec Brook, a small tributary of the River Scorff (Brittany, France), at different stages from the egg to the end of the second growing season. Salmon: zone A = area for egg deposition; zone $\mathrm{C}=$ distribution area of $0+$ parr in autumn and $1+$ parr in spring. zone $\mathrm{B}=$ distribution area of $1+$ parr in autumn. Trout: zone $E=$ area of egg deposition and of distribution of $0+$ juveniles in autumn, zone $\mathrm{D}=$ distribution area of $1+$ trout in spring and autumn. 
the eel density, which remained fairly constant and low all over the brook.

\section{Material and methods}

The data used in this comparative study were collected between October 1982 and April 1985. They concerned the cohort (year class) born in 1983 issuing from the reproduction of the end of 1982 and the beginning of 1983 .

In October 1982 the entire brook was electrofished; the few salmon parr caught were removed and a census of the resident trout spawners was taken.

Adults of (anadromous) salmon and migratory trout (coming from the main river) were sampled at an ascending trap located at $50 \mathrm{~m}$ from the confluence with the main river. They got into the brook only in late autumn; in 1982, the first migrant fish were caught in the beginning of November. Trap efficiency was estimated from capturerecapture methods (Badia \& Poltronieri 1976).

The sizes of the salmon and trout $0+$ juvenile populations were estimated in autumn according to the method of Seber \& LeCren (1967) from electrofishing data ( 2 sweeps). The first downstream $3.9 \mathrm{~km}$ of the brook $\left(6736 \mathrm{~m}^{2}\right)$ was entirely electrofished, whereas only small sectors $\left(312 \mathrm{~m}^{2}\right)$ representative of the uppermost section were. The $0+$ population size of the upper reaches was obtained by multiplying the mean density observed in the sampled sectors by the total area of the zone $\left(2160 \mathrm{~m}^{2}\right)$. Population sizes of $1+$ resident fish in the brook were estimated in the middle of spring (at the end of the downstream migration) and in autumn. The same method for $0+$ fish was used, except for $1+$ trout in the fall. In autumn 1984, electrofishing techniques were stopped upstream when no more $1+$ salmon was caught. The population size of $1+$ trout was derived from the average spatial distribution of the four previous cohorts; the spatial distribution of $1+$ trout was fairly constant from year to year (Baglinière et al. 1989).

Downstream migrating juveniles (parr and smolt stages) were counted at a Wolf trap (Wolf 1951), located immediately above the ascending one (10 $\mathrm{m})$ and operated year round. The brook was totally barred by a fence. The fence and the trap were made of a semirigid plastic net with diamondshaped mesh with sides $5 \mathrm{~mm}$ long. It was impossible for a fish larger than $50 \mathrm{~mm}$ to get through the fence without falling into the trap (the smallest juveniles captured were $25 \mathrm{~mm} \mathrm{FL}$ ). The only way for a fish to avoid the trap was to pass beside the fence, which was only possible during big spates. In 1984 and 1985, no spate occurred during spring, the main downstream migration period. The trap was checked at least twice each day. The median migration date was estimated when $50 \%$ of the migrant juveniles were recorded.

Every trout or salmon caught (by electrofishing or trapping) was measured (fork length, $\mathrm{mm}$ ). The age was determined by scale reading. The sex of spawners was identified. For migratory trout and anadromous salmon, this could be done by visual observation. All the fish trapped were migrating for spawning. Therefore, they were all sexually mature (or maturing). Males and females were easily discriminated because, at the time of the year when they were caught (late autumn), sexual dimorphism was obvious. In resident trout, maturing individuals were detected by serodiagnosis (Maisse, Baglinière \& Lebail 1987) for the females, and by pressure on the flanks for the males. In juveniles, all migrating salmon (except in June 1983) and some migrating and resident $1+$ trout were killed for sex determination and gonad state observation.

Potential egg deposition was calculated using the relations between fecundity (number of ova) and fork length proposed by Euzenat \& Fournel (1976) for trout living in the brook, by Maisse et al. (1987) for trout coming from the main river and by Baglinière \& Maisse (1989) for salmon. Many observations made on fish collected dead after spawning showed that the rate of egg retention was very low.

The redds were localized and counted separately for salmon and trout. No confusion could occur between the two species because redds are always much larger in salmon (the smallest female was $630 \mathrm{~mm} \mathrm{FL}$ ) than in trout (the largest female was $300 \mathrm{~mm}$ FL) (Table 1). The median date of spawning was estimated when $50 \%$ of the redds were dug. For each species, spawning area was defined as the water surface area of the section of the brook extending from the first downstream redd to the last upstream one. The size of particles in the redds was estimated from direct observations using the class scale of Cailleux (1954). According to the method of Witzel \& MacCrimon (1983), which takes into account the particle size distribution in

Table 1. Characteristics of brown trout and Atlantic salmon spawners in Kernec Brook in winter 1982/1983

\begin{tabular}{lcc}
\hline & Trout & Salmon \\
\hline Number of spawners & 642 & 8 \\
Percentage of female & 26.3 & 50.0 \\
$F\{$ Age & 2 to 4 years & 1 and 2 sea-winter \\
$E\{$ & & \\
$M\{$ Mean length $(\mathrm{mm})$ & 205 & 673 \\
$\mathrm{~A}\{$ (min, max) & $(140,300)$ & $(630,770)$ \\
$\mathrm{L}\{$ Mumber of eggs & 52,000 & 24,320 \\
$\mathrm{E}\{$ Num & 17 December & 18 December \\
\hline
\end{tabular}




\section{Baglinière et al.}

the redds, emergence of fry was estimated to occur on average after $765^{\circ} \mathrm{C}$. days for trout and $830^{\circ} \mathrm{C} \cdot$ days for salmon.

The growth rate $(\mathrm{G})$ was defined according to Ricker (1979):

$$
\mathrm{G}=\mathrm{b}\left(\operatorname{Ln}\left(\mathrm{L}_{2}\right)-\operatorname{Ln}\left(\mathrm{L}_{1}\right)\right) /\left(\mathrm{T}_{2}-\mathrm{T}_{1}\right)
$$

where $\mathrm{L}_{1}\left(\mathrm{~L}_{2}\right)$ is the mean size at the time $\mathrm{T}_{1}\left(\mathrm{~T}_{2}\right)$, and $b$ is the allometric coefficient from the fork length-weight relationship (2.90 for trout (Baglinière \& Maisse 1990) and 3.0 for salmon (Baglinière unpublished data)). The mean sizes of fry at emergence were estimated at $23 \mathrm{~mm}$ (trout) and $28 \mathrm{~mm}$ (salmon) from hatchery observations. The length at the end of the first winter was back-calculated for salmon from scale measurements (Baglinière \& Maisse 1989). Bimodality of size distributions was analysed by the Battacharya method (Laurent \& Moreau 1973). Both back-calculated length and winter growth rate were used to determine to which modal group of the bimodal distribution of size at $0+$ age the $1+$ salmon belonged.

The settling rate (S) between two successive stages was calculated as:

$$
\mathrm{S}_{\mathrm{i}}=\mathrm{N}_{\mathrm{i}-1} / \mathrm{N}_{\mathrm{i}}
$$

where $\mathrm{N}_{\mathrm{i}}\left(\mathrm{N}_{\mathrm{i}-1}\right)$ is the number of fish present in the brook at the stage $\mathrm{i}(\mathrm{i}-1)$.

The emigration rate (E) from the $0+$ and $1+$ juvenile populations in autumn after one and two growing seasons was defined as:

$$
E_{i}=M_{i} / N_{i-1} \text {. }
$$

where $M_{i}=$ number of migrants after i season(s) of growth and $\mathrm{N}_{\mathrm{i}-1}=$ number of fish of $(\mathrm{i}-1)+$ age present in the brook in autumn.

The data were analysed by standard statistical methods (chi-square and Student $t$-tests).

\section{Results}

Spawning

Resident and migratory trout (642 fish of which 169 were females) and anadromous salmon ( 8 fish of which 4 were females) spawned in Kernec Brook between the end of 1982 and the beginning of 1983 (Table 1). The whole brook (section E; Fig. 1) was used for spawning by trout, whereas salmon redds were found only in the lower part, up to a distance of $600 \mathrm{~m}$ from the trap (section $\mathrm{A}$; fig. 1). The median dates of spawning were around mid-December and very close for both species. Potential egg deposition of trout was more than twice that of salmon (Table 1). However, density of eggs per unit of spawning area was much higher for salmon $\left(25.6 \mathrm{eggs} \cdot \mathrm{m}^{-2}\right)$ than for trout $\left(5.85 \mathrm{eggs} \cdot \mathrm{m}^{-2}\right)$.
First spring

The average date of emergence was a little later in salmon (28 March) than in trout (20 March). Downstream displacement of juvenile salmon occurred in June 1983 (42 fish caught in the trap). The exact number of fish that left the brook could not be determined because of their small size (FL $<45 \mathrm{~mm})$, too low for totally efficient trapping. No other downstream migration of young of the year salmonids was observed before the fall.

\section{First autumn}

Trout of $0+$ age were distributed throughout the brook with an overall density of 0.291 ind $\cdot \mathrm{m}^{-2}$ (section E; Fig. 1). Salmon juveniles were found over a larger area (section C; Fig. 1), exceeding the spawning zone. The estimated density was 0.089 ind $\cdot \mathrm{m}^{-2}$. The highest densities of $0+$ trout were observed in the headwaters of the brook, outside the zone occupied by salmon and where $1+$ trout and older were also much less abundant (Table 2). The $0+$ trout $/ 0+$ salmon ratio was 1.7 in the overlap zone and 7.3 in the whole brook. Settling rate from the egg stage (Fig. 2) was more than threefold higher (chi-square test, $P<0.001$ ) in trout $(5 \%)$ than in salmon $(1.5 \%)$.

Mean size was slightly higher ( $t$-test, $P<0.01$ ) in trout $(\mathrm{FL}=75 \mathrm{~mm})$ than in salmon $(\mathrm{FL}=73$ $\mathrm{mm}$ ). Trout living together with or without salmon had the same mean fork length. The size distribution of salmon was bimodal (Fig. 3B); 80.4\% of fish belonging to the lower mode. Modal length was $72 \mathrm{~mm}(\mathrm{SD}=8.1 \mathrm{~mm})$ for the lower modal group and $93 \mathrm{~mm}(\mathrm{SD}=8.1 \mathrm{~mm})$ for the lower modal group and $93 \mathrm{~mm}(\mathrm{SD}=4.4 \mathrm{~mm})$ for the upper one. No bimodality in size was detected in trout (Fig. 3A). Although not significant (chisquare test), the growth rate during the first growing season was higher in trout $(0.51)$ than in salmon (0.45). Only one $0+$ spermating fish was caught (118 $\mathrm{mm} \mathrm{FL}$ ) for trout and none for salmon.

After the first growing season

Both species produced migrant and resident fish after one season of growth (Table 3). The migrant/ spring resident ratio was higher (chi-square test, $P<0.01)$ for trout $(0.66)$ than for salmon $(0.32)$. In $1+$ resident salmon, $95 \%$ came from the lower mode of the size distribution at age $0+$ in autumn. No relationship between size at $0+$ age and migration after the first growing season was detected in trout.

Trout (511) and salmon (37) were trapped moving out of the brook (Table 3 ). The period of mi- 


\section{Population dynamics of Atlantic salmon and brown trout}

Table 2. Mean densities (95\% confidence limits) of brown trout in Kernec Brook in 1983 and 1984

\begin{tabular}{|c|c|c|c|c|c|c|c|}
\hline & \multicolumn{7}{|c|}{ Density (ind $\cdot \mathrm{m}^{-2}$ ) } \\
\hline & \multicolumn{3}{|c|}{ Autumn 1983} & \multicolumn{2}{|c|}{ Spring 1984} & \multicolumn{2}{|c|}{ Autumn 1984} \\
\hline & $0+$ & $1+$ & $>1+$ & $1+$ & $>1+$ & $1+$ & $>1+$ \\
\hline Zone with salmon & $0.151( \pm 0.002)$ & $0.062( \pm 0)$ & $0.046( \pm 0)$ & $0.116( \pm 0.002)$ & $0.051( \pm 0)$ & $0.090( \pm 0)$ & $0.027( \pm 0)$ \\
\hline Zone without salmon & $0.404( \pm 0.004)$ & $0.042( \pm 0)$ & $0.015( \pm 0)$ & $0.112( \pm 0.001)$ & $0.038( \pm 0)$ & $0.047( \pm 0)$ & - \\
\hline
\end{tabular}

gration was longer for trout (5 October 1983-10 June 1984) than for salmon (27 November 1983-24 April 1984), but the median dates of migration were similar for both species (6 March for trout and 2 March for salmon). Emigration rate after one season of growth from the $0+$ population was much higher (chi-square test, $P<0.001$ ) in trout than in salmon (Fig. 2). Salmon juveniles migrated as parr $(59 \%)$ and smolts $(41 \%)$, whereas no trout smolt was observed. On average, migrants were larger ( $t$-test, $P<0.01)$ in trout $(\mathrm{FL}=98 \mathrm{~mm})$ than in salmon $(\mathrm{FL}=93 \mathrm{~mm})$. Sex ratios of $1+$ migrating fish were similar in both species $(52 \%$ and $59 \%$ females in trout and salmon respectively; chi- square test, $P>0.05)$. In salmon, $20 \%$ of migrating $1+$ males had matured as $0+$ parr ( 3 fish), whereas no previously mature fish were found in $1+\mathrm{mi}-$ grants of trout.

From the first autumn (1983) to the next spring, the area occupied by trout decreased whereas salmon inhabited the same zone (Fig. 1). The density of resident $1+$ fish was still higher for trout than for salmon. The density of $1+$ trout was similar whether or not the zone was occupied by salmon (Table 2). The trout/salmon ratio of resident fish in the second spring was 4.0 in the sympatry zone and 6.6 for the entire brook. Older trout

\section{A}

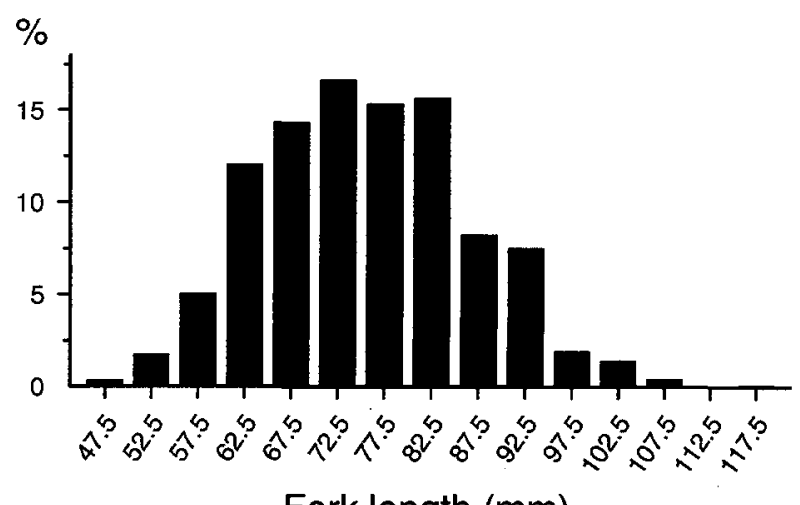

Fork length (mm)

B

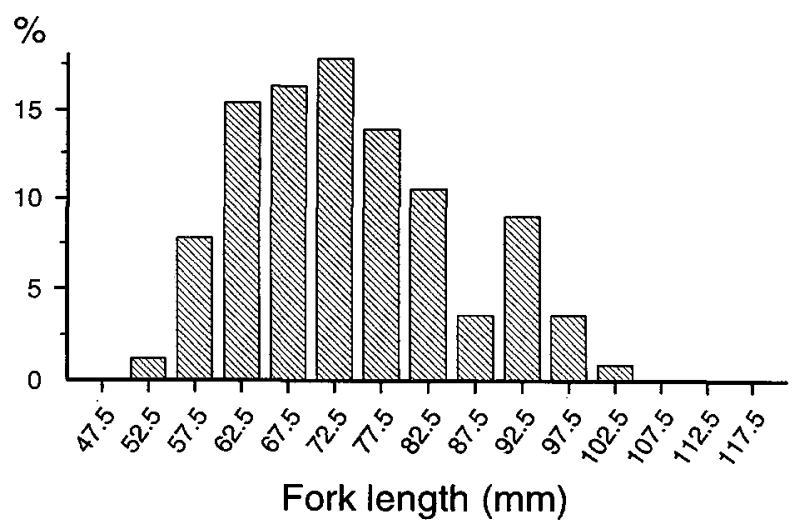

Fig. 3. Size distributions of $0+$ trout $(A ;$ sample size $=1395)$ and $0+$ salmon $(B$; sample size $=332$ ) in autumn 1983 in Kernec Brook. 


\section{Baglinière et al.}

Table 3. Population size of brown trout and Atlantic salmon at different stages in Kernec Brook (cohort 1983)

\begin{tabular}{|c|c|c|c|c|c|c|}
\hline & \multirow{3}{*}{$\begin{array}{l}\text { Potential egg } \\
\text { deposition }\end{array}$} & \multirow{3}{*}{$\begin{array}{c}\text { First } \\
\text { autumn }\end{array}$} & \multicolumn{3}{|c|}{ After first growing season } & \multirow{3}{*}{$\frac{\text { After second growing season }}{\text { migrant }}$} \\
\hline & & & \multirow[b]{2}{*}{ migrant } & \multicolumn{2}{|c|}{ resident } & \\
\hline & & & & second spring & second autumn & \\
\hline Trout & 52,000 & 2586 & 511 & 771 & 431 & 52 \\
\hline Salmon & 24,320 & 354 & 37 & 116 & 56 & 16 \\
\hline
\end{tabular}

(age $>1+$ ) remained more abundant in the zone used by salmon. Settling rate from the $0+$ stage in autumn was similar in both species (Fig. 2).

The size of $1+$ resident fish in spring was larger ( $t$-test, $P<0.001)$, in trout $(\mathrm{FL}=113 \mathrm{~mm})$ than in salmon $(F L=105 \mathrm{~mm})$. The growth rates from the first autumn to the second spring were similar for both species (chi-square test), although slightly lower in salmon ( 0.146 vs 0.158 for trout).

\section{Second autumn}

The area occupied by $1+$ trout in autumn was the same as in spring, while the zone occupied by $1+$ salmon decreased considerably (Fig. 1). The density of $1+$ trout was much higher in the zone of sympatry than in the stretch of the brook without salmon (Table 2). The settling rate of $1+$ resident fish between spring and autumn was not significantly different between the two species (chi-square test; Fig. 2). As a result, the $1+$ trout $/ 1+$ salmon ratio in autumn was 4.2 in the zone colonized by salmon, close to the value of the previous spring. In the whole brook, the ratio was 7.7 and so similar to the values observed in the first autumn and in the second spring.

Trout $(\mathrm{FL}=141 \mathrm{~mm})$ were larger than salmon (FL $=115 \mathrm{~mm} ; t$-test, $P<0.001$ ), and the difference in size between the two species was more pronounced than in the previous spring (Fig. 2). This was related to a much lower growth rate between the second spring and the second autumn in salmon $(0.068)$ than in trout $(0.160$; chi-square test, $P<0.01)$. Compared with the observed values for the period between the first autumn and the second spring, the growth rate remained at the same level during the second growing season for trout whereas it dropped dramatically for salmon. In the second fall, $7 \%$ of the $1+$ trout and $65 \%$ of the $1+$ salmon were spermating males.

\section{After the second growing season}

In contrast to the previous year, emigration rate from the $1+$ resident population was higher (chisquare test, $P<0.01$ ) in salmon than in trout (Fig. 2 ). When moving out of the brook, 52 trout and
16 salmon were trapped (Table 3 ). The migration period was longer in trout (7 September 1984-14 May 1985) than in salmon (1 October 1984-13 April 1985), but salmon tended to migrate later (median date: 31 March) than trout (median date: 23 March). Salmon juveniles migrated as parr $(38 \%)$ and smolts $(62 \%)$, whereas no trout smolt was observed. As for the previous age class, migrants of trout were larger $(\mathrm{FL}=151 \mathrm{~mm})$ than the salmon ones $(\mathrm{FL}=135 \mathrm{~mm})$.

When combining all migrating juveniles of both age classes, the number of migrants per 10,000 eggs (Fig. 2) was 5 times higher in trout (108) than in salmon (22). Production of migrating fish per $\mathrm{m}^{2}$ of area colonized by $0+$ juveniles in autumn was 0.063 for trout and 0.013 for salmon. This figure decreased to 0.006 when taking into account only the production of salmon smolt.

\section{Discussion}

In trout, although some concentration occurred as usual in the upper reaches (Baglinière et al. 1989), the spawning redds were distributed throughout the brook and potential egg deposition was in the range of the values observed in other years (Baglinière et al. 1987b). Unlike trout, salmon laid down a large quantity of eggs in a small spawning zone located in the downstream part of the brook near the confluence with the river. The egg density was the highest ever observed in Kernec Brook from 1977 to 1984 (Baglinière unpublished data) and was well above that of trout or the target levels of ova deposition presented by Kennedy \& Crozier (1993). This high density of eggs most probably induced intraspecific competition in emergent fry, which could have caused density-dependent mortality in situ (Egglishaw \& Shackley 1977; Gee, Milner \& Hemsworth 1978) and/or downstream displacement (as proposed by Mills (1964), Baglinière (1979a), Crisp (1991) and noticed at the trap in June 1983), both factors resulting in low settling rates. This difference in favour of trout compared with salmon is most likely not due to exceptional conditions associated to the cohort studied. For trout, early emigration in spring has never been noted in other years, in agreement with the obser- 


\section{Population dynamics of Atlantic salmon and brown trout}

vations of Elliott (1986), who considered fry losses chiefly due to mortality within the stream rather than to migration, and the 1983 estimate of the settling (survival) rate at the first autumn fell within the range of the values of other cohorts (Baglinière et al. 1989). For salmon, the 1983 settling rate $(1.5 \%)$ was not unusually low, since the figures obtained on year classes, for which no early emigration was observed, were lower $(0.13 \%$ to $0.79 \%$; Baglinière unpublished data).

Poorer survival of salmon compared with trout during the first growing season could be due, at least partly, to increased competition and predation suffered by salmon. Firstly, the $0+$ salmon were restricted to the lower part of the brook. The highest densities were found on the spawning area (zone A; Fig. 1), even though some upstream dispersion from redds was observed. This agrees with earlier observations, as salmon has never been caught above the first $2 \mathrm{~km}$ of the brook (Baglinière unpublished data). Moreover, starting $2 \mathrm{~km}$ upstream of the mouth of the brook, there is a sandy stretch of $1 \mathrm{~km}$ long, much less favourable to young salmon than lower areas regarding habitat requirements of the species (Baglinière \& Champigneulle 1982; Gibson 1993). This section might act as a physical barrier for upstream displacement of juvenile salmon. Secondly, even though the average slope of the lower part of the brook colonized by salmon is favourable to juveniles (Elson 1975; Amiro 1993), the most suitable habitats for young salmon, i.e., the shallow and pebbly riffles (Jones 1975; Karlström 1977; Baglinière \& Champigneulle 1982; Gibson 1993), are not very many. In the other sections of the downstream zone of the brook, with relatively fast running water and coarse bottom substrate, current velocity and proportion of pebbles and stones were below optimal habitat requirements of salmon juvenile (Haury \& Baglinière 1990). For trout, the lower part of the brook presented habitat characteristics close to optimum. Physical parameters (current velocity, bottom substrate and depth), together with the abundance of marginal zones along the banks with overhead cover and deeper water, match the habitat requirements of trout (Karlström 1977; Egglishaw \& Shackley 1982; Baglinière \& Arribe Moutounet 1985; Heggenes 1988; see also the review of Haury, Ombredane \& Baglinière 1991). Under these conditions, trout used every habitat type and could be responsible for restricting the distribution of $0+$ salmon to shallow areas (Karlström 1977; Kennedy \& Strange 1986). Competition with nonsalmonid species, such as sculpin (Gaudin \& Caillère 1990) could have also occurred. It would have had a stronger impact on salmon than on trout because, $0+$ parr were present only in the lower part of the brook where the density of small nonsalmonid fish was the highest, whereas most of the $0+$ trout inhabited the headwaters of the brook where nearly no other species were found. Finally, trout of $1+$ age and older (Mills 1964 and 1969; Kennedy \& Strange 1980; observations made by the authors) and sculpin (Gaudin 1987) are potential predators for $0+$ salmonids. Sculpin and $1+$ trout and older were found at much higher densities in the zone colonized by salmon than in the rest of the brook; in contrast, they were nearly absent in the uppermost section where the majority of the $0+$ trout were found. Consequently, juvenile salmon must have experienced higher predation than trout.

At their first autumn, $0+$ salmon of the same cohort were smaller in Kernec Brook $(F L=73 \mathrm{~mm})$ than in the main river $(\mathrm{FL}=97 \mathrm{~mm}$; Baglinière \& Champigneulle 1986): This corroborates the inverse relationship observed in trout between growth rate and stream order by Baglinière \& Maisse (1990). Therefore, in the brook, a majority of $0+$ salmon belonged to the lower modal group of the size distribution in autumn, whereas the opposite situation was observed in the main stream (Baglinière \& Champigneulle 1986). Migrants after one season of growth came mainly from the upper mode, as showed by Thorpe et al. (1980) under hatchery conditions and verified in the wild by Nicieza, Braña \& Toledo (1991) in Spanish rivers and by Baglinière, Maisse \& Nihouarn (1993) in the Armorican Massif. In the brook, the very small number of $0+$ salmon belonging to the upper modal group resulted in a very low production of $1+$ smolt. Unlike salmon, emigration in trout appeared to be independent of length at the first autumn (Baglinière et al. 1989). This can explain why the migrant-resident ratio after the first growing season was higher for trout than for salmon.

Salmon smoltifies almost exclusively at $1+$ or $2+$ ages in the River Scorff (Baglinière et al. 1987a). The proportion of $2+$ fish in the brook has always been very low and similar to that observed in the main river (Baglinière \& Champignuelle 1986). In contrast, the brook held a large number of $2+$ trout, showing the existence of a resident population (Baglinière et al. 1989). This was confirmed by the lower emigration rate of trout $(12.0 \%)$ compared with salmon $(30.4 \%)$ after the second growing season.

Because of the absence of resident $2+$ salmon parr in the brook, emigration rate at $2+$ age provided a good estimate of survival over the second winter. The observed value $(30.4 \%)$ was very similar to that estimated by Baglinière et al. (1993) for salmon in the Oir system $(32 \%)$, another small brook of the Armorican Massif. Taking into ac- 


\section{Baglinière et al.}

count the results of Maisse et al. (1987) on other cohorts of trout in Kernec Brook, overwinter survival from the second autumn to the next spring would have been higher in trout (between $40 \%$ and $50 \%$ ) than in salmon. This could be due to a higher incidence of sexual maturity at $1+$ age in salmon compared with trout, as strongly suggested by the rates of spermating males at $1+$ age observed in autumn 1984: $7 \%$ in trout vs $65 \%$ in salmon. Indeed, early sexual maturation in Atlantic salmon is common over the geographic range of the species and results in high mortality (Osterdahl 1969; Leyzerovich 1973; Dalley, Andrews \& Green 1983; Hansen et al. 1989), leading to low overwinter survival in $1+$ salmon parr (Baglinière et al. 1993). That probably explained why the small number of salmon leaving the brook after one season of growth was not counterbalanced by a large amount of fish migrating out the next year.

Kernec Brook appeared to be very important for trout recruitment to the main river as well as to the brook itself. On the contrary, it seemed to be only a marginal habitat for salmon: production of migrating fish per $\mathrm{m}^{2}$ of area colonized by $0+$ juveniles in autumn was 0.013 in the brook $(0.006$ when taking into account only smolts) vs 0.035 (exclusively smolt) in the main river (Baglinière \& Champigneulle 1986). Unlike trout, salmon has a life history strategy (migration depends on size, early maturation in freshwater of males, sea growth (almost) indispensable for sexual maturity of females) and riverine habitat requirements that do not fit in with the environmental conditions encountered in such small tributaries as Kernec Brook. Despite this, they might represent zones of refuge, able to ensure the durability of the stock when adverse events affect the best nurseries located in the main river.

\section{Resumen}

1. Hemos comparado la dinámica de la poblaciones de Salmón (Salmo salar) y de Trucha (Salmo trutta), en un afluente pequeño del rio Scorff (Bretaña, Francia), desde el período de puesta hasta el comienzo del tercer periodo de crecimiento.

2. La puesta y la emergencia de juveniles de ambas especies tuvo lugar aproximadamente al mismo tiempo. En el primer otoño, la densidad de juveniles $0+y$ la tasa de colonización desde el estadio de huevo fueron mucho más altas para la trucha que para el salmón, asi como la tasa de emigración para los individuos $0+$. A cualquier edad, el tamaño de los individuos residentes y migratorios fué siempre menor en el salmón que en la trucha.

3. La baja producción de salmón en el rio respecto a la trucha fué el resultado de la baja supervivencia desde el estadio de huevo hasta el estadio $0+$ en otoño, combinado con la pequeña proporción que juveniles que migran después del primer periodo de crecimiento que no estuvo compensado por un mayor número de emigrantes el año siguiente.

4. Discutimos el papel que juega el habitat fisico, la competi- ción inter- e intra-especifica, la predación, la migración dependiente del tamaño y la madurez sexual avanzada. Los resultados indican que afluentes pequeños como el estudiado son de gran valor para el reclutamiento de la trucha pero no para el salmón.

\section{References}

Amiro, P. G. 1993. Habitat measurement and population estimation of juvenile Atlantic salmon (Salmo salar). In: Gibson, R. J. \& Cutting, R. E., ed. Production of juvenile Atlantic salmon, Salmo salar, in natural waters. Canadian Special Publication of Fisheries and Aquatic Sciences 118: 81-97.

Badia, J. \& Poltronieri, G. 1976. Estimation des parametres d'une population par les méthodes de capture-recapture. Département de biométrie et de calcul automatique I.N.R.A., Laboratoire de Biométrie du C. R. de Toulouse, $30 \mathrm{p}$.

Baglinière, J. L. 1979a. Production de juvéniles de Saumon atlantique (Salmo salar L.) dans quatre affluents du Scorff, rivière de Bretagne Sud. Annales de Limnologie 15: 347-366.

Baglinière, J. L. 1979b. Les principales populations de poissons sur une rivière à salmonides de Bretagne Sud, le Scorff. Cybium $3^{\text {ème }}$ série 7: 53-74.

Baglinière, J. L. \& Arribe Moutounet, D. 1985. Microrépartition des populations de truite commune (Salmo trutta L.), de juvéniles de Saumon atlantique (Salmo salar L.) et des autres espèces présentes sur la partie haute du Scorff (Bretagne). Hydrobiologia 120: 229-239.

Baglinière, J. L. \& Champigneulle, A. 1982. Densité de populations de truite commune (Salmo trutta L.) et de juvéniles de saumons atlantique (Salmo salar L.) sur le cours principal du Scorff (Bretagne): préférendums physiques et variations annuelles (1976-1980). Acta Oecologica Oecologia Applicata 3: $241-256$.

Baglinière, J. L. \& Champigneulle, A. 1986. Population estimates of juvenile Atlantic salmon Salmo salar, as indices of smolt production in the R. Scorff, Brittany. Journal of Fish Biology 29: 467-482.

Baglinière, J. L. \& Maisse, G. 1989. Dynamique de la population de juvéniles de Saumon atlantique (Sálmo salar L.) sur un petit affluent du Scorff (Morbihan). Acta Oecologica Oecologia Applicata 10: 1-7.

Baglinière, J. L. \& Maisse, G. 1990. La croissance de la truite commune (Salmo trutta L.) sur le bassin du Scorff. Bulletin français de pêche et de pisciculture 318: 89-101.

Baglinière, J. L., Maisse, G. \& Nihouarn A. 1993. Comparison of two methods of estimating Atlantic salmo (Salmon salar) wild smolt production. In: Gibson R. J. \& Cutting R. E., ed. Production of juvenile Atlantic salmon, Salmon salar, in natural waters. Canadian Special Publication of Fisheries and Aquatic Sciences 118: 189-201.

Baglinière, J. L., Prouzet, P., Porcher, J. P., Nihouarn, A. \& Maisse, G. 1987a. Caractéristiques générales des populations de Saumon Atlantique (Salmo salar L.) des rivières du Massif Armoricain. In: Thibault M. \& Billard R., ed. La restauration des rivières à-saumon. Paris: INRA, pp. 23-37.

Baglinière, J. L., Maisse, G., Lebail, P. Y. \& Prévost E. 1987b. Dynamique de population de truite commune (Salmo trutta L.) d'un ruisseau breton (France). II. Les géniteurs migrants. Acta Oecologica Oecologia Applicata 8: 201-215.

Baglinière, J. L., Maisse, G., Lebail, P. Y. \& Nihouarn, A. 1989. Population dynamics of brown trout, Salmo trutta L., in a tributary in Brittany (France): spawning and juveniles. Journal of Fish Biology 34: 97-110.

Cailleux, A. 1954. Limites dimensionnelles des noms des fractions granulométriques. Bulletin de la Société Géologique de France 4: 643-646.

Crisp, D. T. 1991. Stream channel experiments on downstream movement of recently emerged trout, Salmo trutta L. and salmon, S. salar L. III. Effect of four developmental stages 


\section{Population dynamics of Atlantic salmon and brown trout}

and day and night upon dispersal. Journal of Fish Biology 39: $371-381$.

Dalley, E. L., Andrews, C. W. \& Green, J. M. 1983. Precocious male Atlantic salmon in insular Newfoundland. Canadian Journal of Fisheries and Aquatic Sciences 40: 647-652.

Egglishaw, H. J. 1970. Production of salmon and trout in a stream of Scotland. Journal of Fish Biology 2: 117-136.

Egglishaw, H. J. \& Shackley, P. E. 1977. Growth, survival and production of juvenile salmon and trout in a Scottish stream, 1966-1975. Journal of Fish Biology 11: 647-672.

Egglishaw, H. J. \& Shackley, P. E. 1982. Influence of water depth on dispersion of juvenile salmonids, Salmo salar $\mathrm{L}$. and $S$. trutta L., in a Scottish stream. Journal of Fish Biology 21: 141-145.

Elliott, J. M. 1986. Spatial distribution and behavioural movements of migratory trout Salmo trutta in a lake district stream. Journal of Animal Ecology 55: 907-922.

Elson, P. F. 1975. Atlantic salmon rivers. Smolt production and optimal spawning. An overview of natural production. International Atlantic Salmon Foundation Special Publications Series 6: 96-119.

Euzenat, G. \& Fournel, F. 1976. Recherches sur la truite commune (Salmo trutta L.) dans une rivière de Bretagne, le Scorff. 1. Caractéristiques démographiques des populations de truite commune de la rivière Scorff et ses affluents. 2. Premiers éléments d'une étude de dynamique de population de truite commune. Thèse doctorat $3^{\text {ème }}$ cycle, Biologie animale, Faculté des sciences, Université de Rennes, $213 \mathrm{p}$.

Gaudin, P. 1987. Prédation sur le frai des Salmonidés: exemple des Cottidés. In: Thibault, M. \& Billard, R., ed. La restauration des rivières à saumon. Paris: INRA, pp. 291-296.

Gaudin, P. \& Caillère, L. 1990. Microdistribution of Cottus gobio L. and fry of Salmo trutta L. in a first order stream. Polskie Archiwum Hydrobiologii 37: 81-93

Gee, S. A., Milner, N. J. \& Hemsworth, R. J. 1978. The effect of density on mortality in juvenile Atlantic salmon (Salmo salar). Journal of Animal Ecology 47: 497-505.

Gibson, R. J. 1993. The Atlantic salmon in freshwater: spawning, rearing and production. Reviews in Fish Biology and Fisheries 3: 39-73.

Gibson, R. J. \& Cunjak, R. A. 1986. An investigation of competitive interactions between (Salmo trutta $\mathrm{L}$ ) and juvenile Atlantic salmon (Salmo salar L.) in rivers of the Avalon Peninsula, Newfoundland. Canadian Technical Report of Fisheries and Aquatic Sciences 1472: $82 \mathrm{p}$

Hansen, L. P., Jonsson, B. Morgan, R. I. G. \& Thorpe, J. E. 1989. Influence of parr maturity on emigration of smolting Atlantic salmon (Salmo salar L.). Canadian Journal of Fisheries and Aquatic Sciences 46: 410-415.

Haury, J. \& Baglinière, J. L. 1990. Relations entre la population de truite commune (Salmo trutta L.), les macrophytes et les paramètres du milieu sur un ruisseau. Bulletin français de pêche et de pisciculture 38: 118-131.

Haury, J., Ombredanne, D. \& Baglinière, J. L. 1991. L'habitat de la truite commune (Salmo trutta L.) en cours d'eau. In: Baglinière, J. L. \& Maisse, G., ed. La truite, biologie et écologie. Paris: INRA, pp. 47-96

Heggenes, J. 1988. Physical habitat selection by brown trout (Salmo trutta) in riverine systems. Nordic Journal of Freshwater Research 64: 74-90.

Jones, A. N. 1975. A preliminary study of fish segregation in salmon spawning streams. Journal of Fish Biology 7: 95 104.

Karlström, O. 1977. Habitat selection and population densities of salmon (Salmo salar L.) and trout (Salmo trutta L.) parr in Swedish rivers with some references to human activities. Acta Universitas Upsaliensis 404: 3-12.

Kennedy, G. J. A. \& Crozier, W. W. 1993. Juvenile Atlantic salmon (Salmo salar L.). Production and prediction. In: Gib- son, R. J. \& Cutting, R. E., ed. Production of juvenile Atlantic salmon, Salmo salar, in natural waters. Canadian Special Publication of Fisheries and Aquatic Sciences 118: 179187.

Kennedy, G. J. A. \& Strange, C. D. 1980. Population changes after two years of salmon (Salmo salar L.) stocking in upland trout (Salmo trutta L.) streams. Journal of Fish Biology 17: 577-586.

Kennedy, G. J. A. \& Strange, C. D. 1986. The effects of intraand interspecific competition on the distribution of stocked juvenile Atlantic salmon Salmo salar L., in relation to depth and gradient in an upland trout, Salmo trutta, stream. Journal of Fish Biology 29: 199-214.

Laurent, M. \& Moreau, G. 1973. Influence des facteurs écologiques sur le coefficient de condition d'un téléostéen. Annales d'hydrobiologie 4: 211-228.

Leyzerovich, K. A. 1973. Dwarf males in hatchery propagation of Atlantic salmon. Journal of Ichtyology 13: 382-392.

Maisse, G. \& Baglinière, J. L. 1990. The biology of brown trout, Salmo trutta L., in the River Scorff, Brittany: a synthesis of studies from 1973 to 1984. Aquaculture and Fisheries Management 21: 95-106.

Maisse, G., Baglinière, J. L. \& Lebail, P. Y. 1987. Dynamique de la population de truite commune (Salmo trutta) d'un ruisseau breton (France): les géniteurs sédentaires. Hydrobiologia 148: 123-130.

Mills, D. H. 1964. The ecology of young stages of the Atlantic salmon in the River Bran, Ross-Shire. Freshwater and Salmon Fisheries Research 32, 58 p.

Mills, D. H. 1967. A study of trout and young salmon populations in forest streams with a view of management. Forestry 40 (suppl): $85-90$.

Mills, D. H. 1969. The survival of juvenile Atlantic salmon and brown trout in some Scottish streams. In: Northcote, $\mathrm{T}$. G., ed. Symposium on salmon and trout in streams. H. R. MacMillan Lectures in Fisheries. Vancouver: University of British Columbia, pp. 217-288.

Nicieza, A. G., Braña, F. \& Toledo, M. M. 1991. Development of length-bimodality and smolting in wild stocks of Atlantic salmon, Salmo salar, under different growth conditions. Journal of Fish Biology 38: 509-523.

Nihouarn, A. 1983. Etude de la truite commune (Salmo trutta L.) dans le bassin du Scorff (Morbihan): démographie, reproduction, migration. Thèse Doctorat $3^{\text {eme }}$ cycle, Biologie Animale, Faculté des Sciences, Université de Rennes, 73 p.

Osterdahl, L. 1969. The smolt run of a small Swedish river. In: Northcote, T. G., ed. Symposium on salmon and trout in streams. H. R. MacMillan lectures in fisheries. Vancouver: University of British Columbia, pp. 205-215.

Power, G. 1973. Estimates of age, growth, standing crop and production of salmonids in some north Norwegian rivers and streams. Report of the Institute of Freshwater Research of Drottingholm 53: 78-111.

Randall, R. G., Claytor, R. R., Chadwick, E. M. \& Mortensen, E. 1989. Comparative production of Salmo salar (Atlantic salmon) and Salmo trutta (brown trout) in a small Nova Scotia stream. Proceedings of Nova Scotia Institute of Science 39: $99-109$.

Ricker, W. E. 1979. Growth rates and models. In: Hoar N. S., Randall, D. J. \& Brett, J. R., ed. Fish physiology Vol. 8. London: Academic Press, pp. 643-677.

Seber, G. A. F. \& LeCren, E. D. 1967. Estimating population parameters from large catches relative to the population. Journal of Animal Ecology 36: 631-643.

Shackley, P. E. \& Donaghy, M. J. 1992. The distribution and growth of juvenile Atlantic salmon and trout in the major tributaries of the River Dee catchement (Grampian Region). Scottish Fisheries Research Report 51: 19 p.

Thorpe, J. E., Morgan, R. I. G., Ottaway, E. M. \& Miles, 


\section{Baglinière et al.}

M. S. 1980. Time of divergence of growth groups between potential $1+$ and $2+$ smolts among sibling salmon. Journal of Fish Biology 17: 13-21.

Witzel, D. L. \& MacCrimon, H. R. 1983. Embryo survival and alevin emergence of brook charr, Salvelinus fontinalis, and brown trout, Salmo trutta, relative to the redd gravel composition. Canadian Journal of Zoology 6: 1783-1972.
Wolf, P. 1951. A trap for the capture of fish and other organisms moving downstream. Transactions of the American Fisheries Society 80: $41-45$. 